\title{
The antecedents influencing shoppers' frequencies of visit and purchase intention in the shopping mall: A study on the pull factors
}

\author{
Amy Chu May, YEO, \\ Tunku Abdul Rahman University College, \\ Jalan Genting Klang, \\ Setapak, 5330 Kuala Lumpur, Malaysia \\ yeocm@tarc.edu.my \\ Wei Seng, ONG, \\ SOGO Kuala Lumpur, \\ 190, Jalan Tunku Abdul Rahman, \\ 50100 Kuala Lumpur, Malaysia \\ Henry.ows@klsogo.com.my \\ Choon Ling, KWEK, \\ Tunku Abdul Rahman University College, \\ Jalan Genting Klang, \\ Setapak, 5330 Kuala Lumpur, Malaysia \\ kwekcl@tarc.edu.my
}

\begin{abstract}
The study aims to examine the perceived antecedents that influence the selection of shopping malls and determine the predictive nature of visit frequency that might lead shoppers to the intended purchase. Hence, the research question asked "to what extent the six determinants would most likely to affect shoppers frequency of visit to the malls and their purchase intention". The method employed was positivist paradigm using questionnaires administering to young and adult respondents. A total of 200 usable samples were used for the SPSS analyses. Several primary statistical tools were used such as descriptive analyses, reliability test, factor analysis, multivariate and bivariate regressions. The results revealed that all constructs reliability were above Cronbach alpha 0.70 and both the convergent and discriminant validities were met via the exploratory factor analysis. The finding concluded that convenience, tenant variety, functional attributes, hedonic value and promotion are positively related to the frequency of visit. In addition, frequency of visit is also positively related to the purchase intention. The finding of this research provided both theoretical and practical implications.
\end{abstract}

Keywords: shopping malls, frequency of visit, purchase intention, Malaysia

JEL Classification: M31 


\section{Introduction}

Based on the distinct size and market classification, the types of shopping mall can be classified into convenience, neighbourhood, community, regional, specialty, power, festival/theme and outlet (Peiser \& Frej, 2003). However, the dominance of shopping malls in the retail sector started to decrease mainly due to the emerging of the online shopping (DeLisle, 2005) and the changes of consumer behaviour towards a more selective behaviour (Howard 1993).

The growing numbers of mall influence the ability of customers to differentiate and select malls and this has created a major problem for the retailing sector (Barnes, 2005). This problem has happened in Malaysia particularly in the Klang Valley where it was the most populous area in Malaysia. There are 255 malls in Klang Valley (Begum, 2018) with a total retail supply of about 68.2 million square feet and estimated pipeline supply of 16 million square feet for those who are still under construction (Aziz, 2017). In 2017, 14 malls were expected to open and will have a total net floor area of 6.3 million sq ft. With an expected 17 million square feet of shopping space coming into the Klang Valley from now until 2019, industry experts are alarmed that this will result in an oversupply situation (Mahalingam, 2016). As such, the increasing of retail space has caused the occupancy rate of malls around the Klang Valley dropped significantly from $86.2 \%$ in 2010 to $85.2 \%$ in 2017 (Thean, 2018).

However, it is noted that some of the shopping malls in Klang Valley such as Suria KLCC, Pavilion, Mid Valley, One Utama and Sunway Pyramid are doing particularly well despite many other shopping malls being launched in surrounding their areas. Hence, it is important for developers or mall management to conduct a study or research on why are those shopping malls doing particularly well and identify the factors that will influence the shoppers' frequency of visits to the shopping malls. Furthermore, this has also triggered the interest to study on the attributes that influencing the shoppers' frequency of visit to the shopping mall and their purchase intention. In conclusion, this research would like to investigate what are the contributing success factors mainly based on the "pull" determinants that would influence the frequency of visit and purchase intention amongst the shoppers particularly in the context of Malaysia shopping malls. Hence to fill the research lacuna in this study, we set out our research objectives as follows:

1. To examine the perceived antecedents that influence the selection of shopping malls amongst shoppers;

2. To determine the predictive nature of visit frequency that would lead to the intention to purchase, and; 
3. To provide a more comprehensive framework that aid the shopping mall management or retailers gain a clearer understanding of how shopping malls could be improved and diagnose its specific areas of concern as well as suggest actions to be taken to enhance the shopping experience.

\section{Literature Review}

\subsection{Pull factors of shopping malls}

In view of the prior research done by various researchers, four variables were selected as the main pull factors, such as, accessibility, store assortment or tenant variety, physical environment and marketing variables. Accessibility is related to the mall location and convenience whereas store assortment or tenant variety is related to the selection of store or anchor store and leisure offering. Next, physical environment is related to the ambience or Functional Attributes of the mall or characteristics of the mall and finally marketing variables include promotion and communication. Besides, there is a numerous stream of theories and research support that through the satisfaction of using the service or product offering, it will affect the customer intention to purchase and opt for the service again (Oliver et al., 1997). As such, it can undertake that customers' satisfaction will affect their intention of revisiting the mall and subsequently increase the frequency of visits and thus, resulting in their purchase intention. Therefore, to reflect the variables that indicating the consumers' attraction to the mall, this study includes the above variables namely frequency of visits and purchase intention (Pan \& Zinkhan, 2006), since both are the main performance indicators of attractiveness of the mall. According to Chebat et al. (2014), frequency of visits means that how often the consumer shop at the shopping mall or also known as the visit rate.

\subsubsection{Convenience}

Past research singled out that consumers recognize that convenience shopping experience is equal to the reduction of the consumption of time and effort consumed in the purchasing process (Pan \& Zinkhan, 2006).

El-Adly \& Eid (2015) and El Hedhli et al. (2013) found that convenience of shopping mall by all means reflecting the capability of the shopping mall in providing customers the opportunity to perform a wide range of shopping tasks 
with reduced effort and time. Shopping malls can also offer time convenience through the one-stop shopping concept, operations hour extension, a closed and safe environment and also the location that is near to the place that shoppers work or living into (Clulow \& Reimers, 2009). Consequently, majority of the shopping malls nowadays emphasize and offer shoppers conveniences such as customer-friendly operating hours, ample of parking spaces and facilities, located in strategic location and provide all sorts of merchandise in a special point of sale (Yan \& Eckman, 2009).

Anselmsson (2016) also states that accessibility or location can be separated into two aspects namely, internal and external access. Internal access is looking into the internal variables that are related to internal access of shopping areas such as isles, elevators, signposting and informative display in order for customer to move freely around. Whereas, external access look into the broad view of shopping malls that include variables such as business hours, parking and accessibility of public transportation. Besides, shoppers also perceive the existence of security officers within the mall premise as part of the convenience aspects of mall, in which the existence of security officers will affect the shopper's patronage behaviour (Bloch et al., 1994).

Invariably, past research also proved that easy access is significantly positive related to the selection of shopping mall that is crucial to the patronage of mall (Raajpoot et al., 2008). Chebat et al. (2010) and Kesari and Atulker (2016) advocated that mall convenience has a strong relationship with customers' satisfaction towards the mall, as well as on the frequency of visit to the shopping mall (Clulow \& Reimers, 2009). Henceforth, this leads us to the proposed hypothesis as follow:

H1. The convenience of the shopping mall has a positive relationship with the frequency of visits.

\subsubsection{Tenant Variety}

Shopping mall is an accumulation center for various retailers or tenants. Large trading area in the shopping mall integrates a great number and different types of store within a single area which are able to attract shoppers, and will also allow the shoppers to discover an extensive range of merchandise offered by the stores that located in the shopping mall (El-Adly \& Eid, 2015). As such, tenant variety or what also known as the shopping mall's retail tenant mix is one of the most important components to the attraction of shopping mall as it closely relates to the fundamental benefit on the shopping experience (Anselmsson, 2016). 
A number of studies have been conducted to prove that tenant assortment will influence shoppers behavioural responses (Pan \& Zinkhan, 2006; Borgers \& Vosters, 2011). In fact, according to Chebat et al. (2010), shoppers who patronize a mall with a better retail assortment are able to satisfy their needs more than the malls with a lower store assortment. Wakefield and Baker (1998) as well as Sinha and Banerjee (2004) argue that shopping malls with wide range of branded stores (such as departmental stores, apparel stores \& grocery stores) that providing good access of multiple brands are likely to gain the frequency of visit from the shoppers.

Besides, the tenant variety can also be related to the type of entertainment or amusement offered in the shopping mall. Other than that, several authors also highlight the prominence of anchor tenant as anchor tenant plays a decisive factor in defining the efficiency of shopping mall (Finn \& Louviere, 1996; Damian et al., 2011). To be more precise, anchor tenant in a shopping mall directly influences the sales as well as the shoppers' intention to visit (Damian et al., 2011). In addition, past research conducted by Pan and Zinkhan (2006) also suggested that tenant variety will directly influence the frequency of visits to the mall. As such, a broad choice of tenant mix not only able to attract more customers, but also able to increase the chances of purchasing when they are visiting the shopping mall, since the cost of time and effort are significantly lower.

Based on the previous results, we then proposed the following hypothesis:

H2. The tenant variety is positively related to the frequency of visits.

\subsubsection{Functional Attributes}

According to El Hedhli et al. (2013), the mall's functional attributes relate to the way in which a particular mall is perceived by shoppers regarding a set of functional attributes for instance products and services offered and a set of psychological attributes. To be more specific, a mall's functional attributes relate to the internal ambience, atmosphere and aesthetics, which will include the environmental elements such as music, colour and crowding (Chebat et al., 2010).

There are mainly five major categories of mall environment as defined by Raajpoot et al. (2008), which includes exterior, layout, general interior, interior display and human variables; and these categories are also known to affect the outcome 
variables such as time spent in the mall, re-visit intention and overall evaluation. Besides, Raajpoot et al. (2008) also propose that the functional attributes might include the appearance of the mall, the design of the interior, the internal lighting, visual set up, the odours or what known as aroma and also the music used. All these mentioned features directly engage with the senses which are likely to play a crucial role in affecting the shopper satisfaction. As such, for this research, the mall environment will be conceptualized as the general ambiance and impressions of the shopping mall as observed by shoppers.

Kotler (1973) argues that the internal atmosphere directly influences the customer experience specially on their senses, in which it eventually increases the probability of mall patronization. Besides, a tidy shopping mall with attractive atmosphere will also create a pleasant environment for friends and family to meet and hangout or simply just to interact with peers (El-Adly \& Eid, 2015).

On another hand, Tarun et al. (2017) discover that separate play zones for kids is also another types of functional attributes that shows a positive relationship towards the frequencies of visit to shopping mall. Contrariwise, if a mall is in a poor atmospherics or ambience, shoppers will demotivate or feel reluctant to visit the mall and hence, directly reduces their purchasing intention at the shopping mall (El Hedhli et al., 2013). Similarly, a shopping mall should be apparent as pleasant, for that reason, mall may offer comfortable internal temperature and rest areas, with the pleasant atmosphere, the shopping mall patronage is likely to increase (Chebat et al., 2010). Previous research found that the shopping mall's internal atmospheric influences the building of customer footfall and traffic, the customer satisfaction and in frequency of visit (Dennis et al., 2010; Anselmsson, 2006; Chebat et al., 2014). As such, traits that are related to image, appearance, style and aesthetics are relevant in driving the frequency of visit to the mall.

The above literature leads to the proposed hypothesis as follows:

H3. The functional attributes of the shopping mall is positively related to the frequency of visits.

\subsubsection{Hedonistic Value}

The entertainment factor of hedonic shopping is reflected as the most crucial competitive tool which directly influences the selection of shopping mall to patronage (Kesari \& Atulkar, 2016). The trend of going to a shopping mall has been largely related to the leisure time enjoyment activity, which is way beyond the functional utility by providing hedonistic values that represent fulfilling and grateful experience for shoppers (Kim \& Kim, 2008). 
Past studies also recognize several factors in the mall environment may contribute to the pleasant shopping experiences. To be exact, entertainment or amusement facilities are recognized as tools to create hedonic shopping values, since these facilities are able to create excitement and enjoyment during the shopping process. Entertainment or amusement facilities include music, events areas, cinemas, food courts, gaming areas and recreational areas (Kesari \& Atulkar, 2016). In reality, shopping mall management has been much emphasized on the food and restaurant as it has become a main tool to distinguish themselves from competition when establishing a new malls. Likewise, to maintain the constant traffic flow of the shopping mall, mall management also includes a series of events that occurred in the mall such as celebrity meet up, new product launching, musical performances, special occasion events and also other social functions (Anselmsson, 2016). Besides, anchor tenant also remain a dominant role in attracting and maintaining the footfall or traffic flow in the mall (Finn \& Louviere, 1996; Damian et al., 2011).

As such, shopping malls' entertainment or amusement facilities not just enrich leisure offering but also engage social interaction through activities such as going to the cinema or have a meal (El Hedhli et al., 2013). Therefore, it can be concluded that mall hedonistic value is related to the mall leisure offering.

To conclude, various research have proved that through leisure offering such as mall entertainment outlet, it able to create excitement amongst the shoppers and consequently, develop and improve the shopping mall competitiveness (Wakefield \& Baker, 1998; Ali \& Anuar, 2013). Besides, El Hedhli et. al. (2013) also state that frequency of visit to the mall is positively connected to hedonistic value. Contingent upon the above hedonistic behaviour of shopper, this research hypothesised that:

H4. The hedonistic value shoppers gained from the shopping mall is positively related to the frequency of visits

\subsubsection{Marketing Promotion}

Past research done on the shopping malls highlight that communication and promotional activities are one of the crucial factors that create good customer experience (Ailawadi et al., 2009; Grewal et al., 2009). Monetary saving is found to be an important criterion when selecting a shopping mall to patronize. As such, 
studies as conducted by Bettman (1979) and Sinha and Banerjee (2004), prove that if mall frequently provides good discount rates is likely to draw shoppers intention to patronize the mall.

In addition, past research done by Chebat et al. (2010) also proves that the malls' frequency and depth of promotional activities, as well as level of prices, will influence the frequency of visits towards the mall. Similarly, study done by Anselmsson (2006) also proves that there is also a positively significant relationship between promotional activities with customers' satisfaction, in which it directly impacts the frequency of visits to the shopping mall. Promotional activities as mentioned by Anselmsson (2006) include, advertising frequency, media exposure and attractiveness of promotional offerings.

As such, to conclude, it proves that customers or shoppers are more preferred to visit the mall that offers extensive range of promotional activities and will hold a more favourable attitudes towards the mall and hence increase the frequency of visits to the shopping mall.

Based on the above findings, this research hypothesized that promotional activities carried by the shopping mall would attract more potential shoppers.

H5. The shopping mall marketing promotions are positively related to the frequency of visit.

H6: Given the perceived antecedents, there is a positive relationship between frequency of visit and purchase intention.

Figure 1 - Conceptual Framework

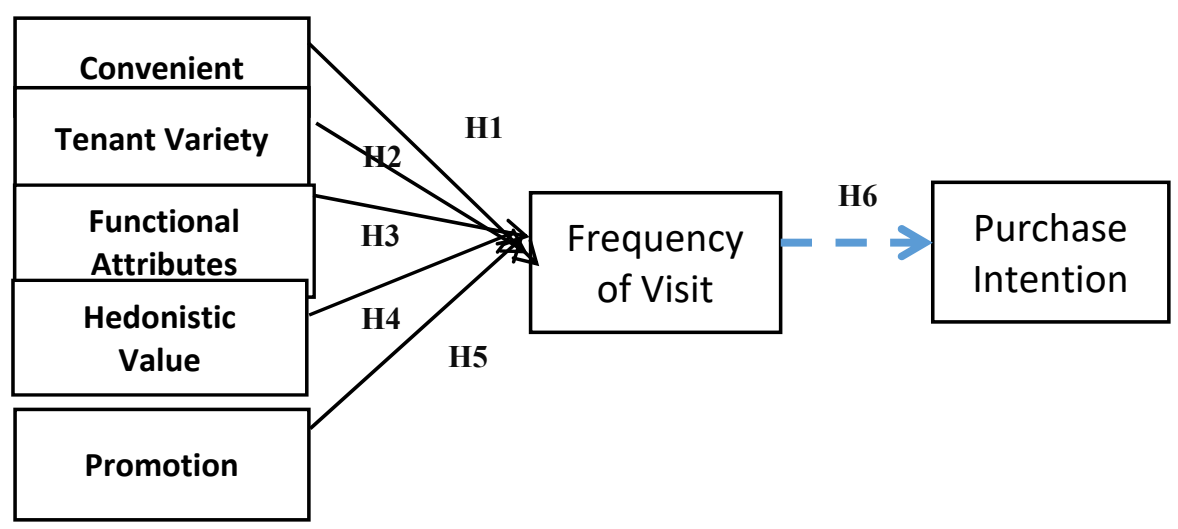




\section{Research Methodology}

\subsection{Research Design}

The research was conducted by using quantitative study based on positivist paradigm. Quantitative research is usually associated with deductive approach using data acquired to assess on theory. The researcher used a correlation design to describe the characteristic of the independent variables, which include convenience, tenant variety, functional attributes, hedonistic values and marketing promotions that have an effect on the dependent variable, frequency of visits and its potential impact on purchase intention. Primary data and crosssectional study were adopted in the research.

\subsection{Samplings and Sample Size}

We employed snowball sampling technique (ie: referral sample) to amass data. The rationale of this technique being chosen was due to the initial respondent has a close social network to refer, and hence, it may help to reach a larger population that could potentially contribute to the study. For this study, a total of 260 questionnaires were distributed to a list of shoppers mainly in the areas of Kuala Lumpur and Klang Valley. As these areas show the highest urbanisation rate, particularly Kuala Lumpur with $100 \%$ of urbanisation rate and Selangor which recorded 91.4\% (Department of Statistics Malaysia, 2011). A total of 200 completed and usable samples were used for the analyses.

\subsection{Survey Instrument}

The questionnaire design consisted of two parts which can be divided into Section A - Determinants of frequency of visit and purchase intention in Shopping Malls and Section B - Demographic characteristics of the respondents. Section A consisted 26 questions to investigate the determinants of frequency of visit and purchase intention in shopping malls. Five point Likert Scales were implemented in scaling responses for all the variables tested in the survey, ranging from strongly disagree (1) to strongly agree (5). The convenience variable was measured by five items sourced from Bloch et al (1994). Whereas, the tenant variety variable was measured by five items that adapted from Bellenger et al (1997). Five items were adapted from Wakefield and Baker (1998) as scales to measure the variable of 
functional attributes. The hedonistic value was measured by three items that adapted from Bloch et al (1994). Three items were adapted from Munuera \& Cuestas (2006) as scales to measure the variable marketing promotions. Lastly, two items were adapted from Wakefield \& Baker (1998) as scales to measure the variables frequency of visits and purchase intention respectively. Section B contained the demographic factors such as gender, age and household typology. The demographic profiles are important in this research as it helps the researcher to gain insight and investigate on the factors of public choose a shopping mall to visit.

Pilot test was conducted prior to the actual data collection. The objective of pilot test is to confirm and refine the questionnaire to ensure there will be no issue in recording data for analysis (Saunders et al., 2012). Based on the feedback from the pilot test, some minor amendments were made before we distributed to the targeted respondents via Google Form method. This online mode survey method was used because it can be easily accessed via all kinds of electronic devices such as computer, tablet and hand phone. Google form is one of the common tools for researchers whereby survey can be created and information can be gathered and all the data will be generated into an online spreadsheet. Then, researcher can transform the data from the spreadsheet into the statistical software. Statistical Package for the Social Sciences (SPSS) version 21 was used for data analysis after all the data had been gathered.

\section{Data Analysis}

\subsection{Descriptive Analysis - Demographic Profile}

Table 1 elaborated the frequency distribution of the demographic profile, a total of 200 respondents were participated in the survey. Among the 200 respondents, a total of 158 respondents were female (79.0\%) whereas male respondents consist of 42 persons (21.0\%). As for the age group, the data shown that the majority of the respondents, which consists of 123 respondents (61.5\%), are belong to the age group of $21-29$ years of age. This is considered acceptable to examine the factors of shopping mall patronage intention in general as the median age amongst Malaysian population as published by Department of Statistics of Malaysia (2011) is 26.2 years. In terms of household typology, majority of the respondents are individual adults and it consists of 120 of respondents (60.0\%). 
Table 1: Demographic Profile Analysis

\begin{tabular}{|c|c|c|c|}
\hline $\begin{array}{c}\text { Demographic } \\
\text { Variable }\end{array}$ & Indicator & Frequency & Percentage \\
\hline \multirow[t]{2}{*}{ Gender } & Male & 42 & 21.0 \\
\hline & Female & 158 & 79.0 \\
\hline \multirow[t]{5}{*}{ Age } & $16-20$ years old & 7 & 3.5 \\
\hline & 21-29 years old & 123 & 61.5 \\
\hline & 30-39 years old & 17 & 8.5 \\
\hline & 40-49 years old & 28 & 14.0 \\
\hline & 50 and above & 25 & 12.5 \\
\hline \multirow{6}{*}{$\begin{array}{l}\text { Household } \\
\text { Typology }\end{array}$} & Individual adult & 120 & 60.0 \\
\hline & $\begin{array}{l}\text { Family unit with small children } \\
\text { (less than } 6 \text { years old) }\end{array}$ & 12 & 6.0 \\
\hline & $\begin{array}{c}\text { Family unit with children } \\
\text { (6-18 years old) }\end{array}$ & 28 & 14.0 \\
\hline & $\begin{array}{l}\text { Family unit with children } \\
\text { (18 years and older) }\end{array}$ & 30 & 15.0 \\
\hline & Couple with children living their own & 3 & 1.5 \\
\hline & Retired & 7 & 3.5 \\
\hline
\end{tabular}

\subsection{Descriptive Analysis - Correlation and Multicollinearity}

Table 2 highlights that all the variables are associated to each other. The values of Pearson Correlation Coefficient is ranging from 0.230 (weak correlation between hedonistic value and purchase intention) to 0.842 (strong correlation between convenience and functional attributes). Besides, the values of VIF is ranging from 1.972 to 4.912, which is far below the cut-off point of 5 (Hair et al 2014). In other words, multicollinearity is not an issue for this study.

Table 2: Correlation and Multicollinearity

\begin{tabular}{|l|c|c|c|l|l|l|l|l|l|l|}
\hline Variables & Mean & $\begin{array}{l}\text { Standard } \\
\text { Deviation }\end{array}$ & VIF & T_C & T_TV & T_FA & T_HV & T_P & T_FV & T_PI \\
\hline T_C & 18.99 & 4.06 & 4.912 & - & & & & & & \\
\hline T_TV & 18.60 & 3.95 & 3.577 & $0.791^{*}$ & - & & & & & \\
\hline T_FA & 18.77 & 4.09 & 4.689 & $0.842^{*}$ & $0.800^{*}$ & - & & & & \\
\hline T_HV & 11.30 & 2.60 & 3.378 & $0.781^{*}$ & $0.734^{*}$ & $0.792^{*}$ & - & & & \\
\hline T_P & 15.05 & 3.26 & 3.833 & $0.806^{*}$ & $0.787^{*}$ & $0.793^{*}$ & $0.765^{*}$ & - & & \\
\hline T_FV & 7.15 & 1.77 & 1.972 & $0.682^{*}$ & $0.582^{*}$ & $0.627^{*}$ & $0.629^{*}$ & $0.614^{*}$ & - & \\
\hline T_PI & 6.09 & 1.91 & - & $0.314^{*}$ & $0.264^{*}$ & $0.260^{*}$ & $0.230^{*}$ & $0.317^{*}$ & $0.257^{*}$ & - \\
\hline
\end{tabular}

*Correlation is significant at the 0.01 level (2-tailed).

T_C (Convenient); T_TV (Tenant Variety); T_FA (Functional Attribute); T_HV (Hedonistic Value); T_P (Promotion); T_FV (Frequency of Visit); T_PI (Purchase Intention) 


\subsection{Reliability Test}

Reliability test was carried out to measure the internal consistency through the Cronbach alpha reliability analysis. The reliability test result as summarised in Table 3 revealed that all the multi-item scale for every variables such as convenience, tenant variety, Functional Attributes, Hedonistic Value, communication and promotion, frequency of visit and purchase intention with Cronbach alpha value of $0.807,0.808,0.812,0.710,0.773,0.778$ and 0.769 respectively. The Cronbach Value shown that all variables have a value that higher than the rule of thumb, which is 0.7 (Hair et al., 2014). As such, this means that the research instrument generally has adequate reliability to proceed to following analysis. In short, the multi-item scale is reliable to be used in the study.

Table 3: Reliability and Factor Analysis

\begin{tabular}{|c|c|c|c|c|c|}
\hline Factors & Variables & $\begin{array}{l}\text { Factor } \\
\text { Loading }\end{array}$ & $\begin{array}{l}\text { Eigen- } \\
\text { value }\end{array}$ & $\begin{array}{l}\text { Percentag } \\
\quad \text { e of } \\
\text { Variance } \\
\text { Explained }\end{array}$ & $\begin{array}{c}\text { Cronbach's } \\
\text { Alpha }\end{array}$ \\
\hline \multirow{5}{*}{ Convenience } & $\begin{array}{l}\text { I would like to visit a } \\
\text { mall with an easy and } \\
\text { convenience } \\
\text { accessibility. }\end{array}$ & 0.716 & \multirow{5}{*}{11.711} & \multirow{5}{*}{45.043} & \multirow{5}{*}{0.807} \\
\hline & $\begin{array}{l}\text { I would visit a mall } \\
\text { which I feels safe with } \\
\text { the mall security. }\end{array}$ & 0.685 & & & \\
\hline & $\begin{array}{l}\text { Mall with a spacious } \\
\text { retail and physical } \\
\text { facility would attract } \\
\text { me to visit the mall. }\end{array}$ & 0.684 & & & \\
\hline & $\begin{array}{l}\text { I would visit a mall } \\
\text { with free parking. }\end{array}$ & 0.683 & & & \\
\hline & $\begin{array}{l}\text { I would like to visit a } \\
\text { mall which have a } \\
\text { good customer } \\
\text { services. }\end{array}$ & 0.668 & & & \\
\hline \multirow{2}{*}{$\begin{array}{l}\text { Tenant } \\
\text { Variety }\end{array}$} & $\begin{array}{l}\text { I would visit a mall } \\
\text { which has a good } \\
\text { access of multiple } \\
\text { brands. }\end{array}$ & 0.694 & \multirow{2}{*}{8.071} & \multirow{2}{*}{51.053} & \multirow{2}{*}{0.808} \\
\hline & $\begin{array}{l}\text { I would visit a mall } \\
\text { that is having a } \\
\text { hypermarket/superm } \\
\text { arket. }\end{array}$ & 0.690 & & & \\
\hline
\end{tabular}




\begin{tabular}{|c|c|c|c|c|c|}
\hline & $\begin{array}{l}\text { I would visit a mall } \\
\text { which has a wide } \\
\text { range of products } \\
\text { offers. }\end{array}$ & 0.684 & & & \\
\hline & $\begin{array}{l}\text { I would visit a mall } \\
\text { that have a renowned } \\
\text { retailers and } \\
\text { franchises. }\end{array}$ & 0.675 & & & \\
\hline & $\begin{array}{l}\text { The mall would be my } \\
\text { choice with presence } \\
\text { of related services } \\
\text { (bank, mobile } \\
\text { companies, etc). }\end{array}$ & 0.669 & & & \\
\hline \multirow{5}{*}{$\begin{array}{l}\text { Functional } \\
\text { Attributes }\end{array}$} & $\begin{array}{l}\text { I would prefer a mall } \\
\text { which provides a } \\
\text { separate play zones } \\
\text { for children/kids. }\end{array}$ & 0.753 & \multirow{5}{*}{4.817} & \multirow{5}{*}{53.421} & \multirow{5}{*}{0.812} \\
\hline & $\begin{array}{l}\text { I would choose a mall } \\
\text { with adequate } \\
\text { rest/comfortable } \\
\text { areas. }\end{array}$ & 0.734 & & & \\
\hline & $\begin{array}{l}\text { The attractiveness of } \\
\text { the mall's facilities } \\
\text { and Functional } \\
\text { Attributes would } \\
\text { influence the choice } \\
\text { of malls. }\end{array}$ & 0.708 & & & \\
\hline & $\begin{array}{l}\text { I would choose a mall } \\
\text { that equipped } \\
\text { sufficient signposting. }\end{array}$ & 0.703 & & & \\
\hline & $\begin{array}{l}\text { A mall with an } \\
\text { attractive } \\
\text { architecture would } \\
\text { trigger my interest to } \\
\text { visit. }\end{array}$ & 0.684 & & & \\
\hline \multirow{3}{*}{$\begin{array}{c}\text { Hedonistic } \\
\text { Value }\end{array}$} & $\begin{array}{l}\text { I would visit a mall } \\
\text { with a variety choice } \\
\text { of food and } \\
\text { restaurants. }\end{array}$ & 0.728 & \multirow{3}{*}{4.559} & \multirow{3}{*}{58.238} & \multirow{3}{*}{0.710} \\
\hline & $\begin{array}{l}\text { I would visit a mall } \\
\text { that is having cafes } \\
\text { and coffee shops. }\end{array}$ & 0.708 & & & \\
\hline & $\begin{array}{l}\text { I would visit a mall } \\
\text { that is having } \\
\text { cinemas/movie } \\
\text { theatres. }\end{array}$ & 0.696 & & & \\
\hline
\end{tabular}




\begin{tabular}{|c|c|c|c|c|c|}
\hline \multirow{4}{*}{ Promotion } & $\begin{array}{l}\text { Mall that has a } \\
\text { frequent } \\
\text { communication } \\
\text { activities and } \\
\text { promotions would } \\
\text { attract me to pay a } \\
\text { visit. }\end{array}$ & 0.744 & \multirow{4}{*}{3.842} & \multirow{4}{*}{62.797} & \multirow{4}{*}{0.773} \\
\hline & $\begin{array}{l}\text { Mall that always } \\
\text { provides good } \\
\text { discount would } \\
\text { attract me to visits } \\
\text { frequently. }\end{array}$ & 0.715 & & & \\
\hline & $\begin{array}{l}\text { Mall that has a } \\
\text { good/attractive sales } \\
\text { promotion would } \\
\text { attract me to pay a } \\
\text { visit. }\end{array}$ & 0.633 & & & \\
\hline & $\begin{array}{l}\text { Mall that provides a } \\
\text { common membership } \\
\text { privilege amongst } \\
\text { tenant would attract } \\
\text { my visits. }\end{array}$ & 0.626 & & & \\
\hline \multirow{2}{*}{$\begin{array}{c}\text { Frequency } \\
\text { of Visit }\end{array}$} & $\begin{array}{l}\text { I would have an } \\
\text { intention to revisit } \\
\text { the mall that suits my } \\
\text { preferences. }\end{array}$ & 0.716 & \multirow[t]{2}{*}{3.181} & \multirow[t]{2}{*}{66.638} & \multirow[t]{2}{*}{0.778} \\
\hline & $\begin{array}{l}\text { I would frequently } \\
\text { visit the shopping } \\
\text { mall of my choice. }\end{array}$ & 0.551 & & & \\
\hline \multirow{2}{*}{$\begin{array}{l}\text { Purchase } \\
\text { Intention }\end{array}$} & $\begin{array}{l}\text { I would have an } \\
\text { intention to purchase } \\
\text { when I visit the mall. }\end{array}$ & 0.942 & \multirow{2}{*}{1.563} & \multirow{2}{*}{69.819} & \multirow{2}{*}{0.769} \\
\hline & $\begin{array}{l}\text { I would like to buy } \\
\text { goods and services } \\
\text { when I visit the mall. }\end{array}$ & 0.891 & & & \\
\hline
\end{tabular}

Note: KMO Measure of Sampling Adequacy $=0.953 ; p=0.000$ (p<0.05); $d f=325 ;$ Approx. ChiSquare $=2675.667$

\subsection{Validity Test}

Constructs validity via exploratory factor analysis was carried out to examine the validity of the measurement. According to Table 3, the value of Kasier-Meyer-Olkin test is 0.953 in which it means that the sample size is adequate. Besides, Bartlett's test of Sphericity is conducted to calculate the correlation of matrix between pairs of variables. The results shown in Table 3 
indicate that the $p$ value is 0.00 which is less than 0.05 , hence, correlations between variables is significantly different from zero (ie., different from an identity matrix). In addition, all the values of factor loading are more than 0.5. In conclusion, the measurement scales fulfill the conditions of convergent and discriminant validities.

\subsection{Inferential Analysis: Multiple Regression Analysis}

In Table 4, the $R$ value was shown 0.702 . This indicate that there was a moderate association between convenience, tenant variety, functional attributes, hedonistic value and communication \& promotion towards the frequency of visits. Coefficient of determination or $\mathrm{R}$ square indicates the variation percentage in dependent variable explained by all independent variables as a set. $R$ square was 0.493 as shown in Table 4, which means that all predictors of convenience, tenant variety, Functional Attributes, Hedonistic Value and communication \& promotion accounted for $49.3 \%$ of variability in shoppers' frequency of visits. Besides, it can be concluded that convenience, tenant variety, functional attributes, hedonistic value and promotion are found to be significant based on the $p$ value, which is less than 0.05 and all the unstandardised beta coefficient are above zero. As such, it can conclude that there is a positive relationship between convenience, tenant variety, functional attributes, hedonistic value and communication $\&$ promotion with frequency of visits.

Table 4 - Multiple Regression Analysis (H1 to H5)

\begin{tabular}{|l|c|c|c|c|c|}
\hline Predictors & $\begin{array}{l}\text { Unstandardized Beta } \\
\text { Coefficients }\end{array}$ & t-value & Significant & \multicolumn{2}{|c|}{$\begin{array}{c}\text { 95\% } \\
\text { Confidence Interval }\end{array}$} \\
\cline { 4 - 6 } & 0.298 & 13.121 & 0.000 & 0.253 & 0.343 \\
\hline Convenience & 0.261 & 10.083 & 0.000 & 0.210 & 0.312 \\
\hline Tenant Variety & 0.272 & 11.312 & 0.000 & 0.225 & 0.319 \\
\hline $\begin{array}{l}\text { Functional } \\
\text { Attributes }\end{array}$ & 0.419 & 11.383 & 0.000 & 0.355 & 0.504 \\
\hline $\begin{array}{l}\text { Hedonistic } \\
\text { Value }\end{array}$ & 0.334 & 10.949 & 0.000 & 0.274 & 0.394 \\
\hline Promotion & & & & & \\
\hline
\end{tabular}

Note: Dependent variable: Frequency of visit

$\mathrm{R}=70.2$ percent; $\mathrm{R}$ Square $=49.3$ percent; Adjusted $\mathrm{R}$ Square $=48$ percent 


\subsection{Inferential Analysis: Bivariate Regression Analysis}

From Table 5 shown as below, the $R$ value was 33.6 percent. This indicate that there was a moderate association between the frequency of visits and purchase intention. Coefficient of determination or $\mathrm{R}$ square indicates the variation percentage in dependent variable explained by all independent variables as a set. The value of $R$ square was 11.3 as shown in Table 5, which means that the frequency of visit accounted for $11.3 \%$ of variability in shoppers' purchase intention. Besides, it can be concluded that frequency of visit is found to be positively significant on the purchase intention, based on the $p$ value which is less than 0.05 and the value of unstandardised beta coefficient is 0.549 . In conclusion, it can conclude that there is a positive relationship between frequency of visit and purchase intention.

Table 5 - Bivariate Regression Analysis (H6)

\begin{tabular}{|l|c|c|c|c|c|}
\hline Predictors & $\begin{array}{l}\text { Unstandardized Beta } \\
\text { Coefficients }\end{array}$ & t-value & Significant & \multicolumn{2}{|c|}{$\begin{array}{c}95 \% \\
\text { Confidence Interval }\end{array}$} \\
\cline { 3 - 6 } & & & & $\begin{array}{l}\text { Lower } \\
\text { Brequend } \\
\text { visit }\end{array}$ & $\begin{array}{c}\text { Upper } \\
\text { Bound }\end{array}$ \\
\hline
\end{tabular}

Note: Dependent variable: Purchase Intention

$\mathrm{R}=33.6$ percent; $\mathrm{R}$ Square $=11.3$ percent; Adjusted $\mathrm{R}$ Square $=10.9$ percent

\section{Discussion}

The main objective of this study is to investigate the factors influencing the frequencies of visit and purchase intention of shoppers in the shopping mall context. The finding of this study concludes that convenience has a positive significant relationship with the frequency of visits, which is supported Chebat er al. (2010). Besides, this study also concludes that there is a significant positive relationship between tenant variety towards the frequency of visits in which the finding supported by Damian et al. (2011). In addition, functional attributes of shopping mall have exerted a significant positive relationship with frequency of visits in which the finding is in align with the argument from Chebat et al. (2010). It was also found that there is a significant positive relationship between hedonistic value and frequency of visits, which is supported by Wakefield and Baker (1998). Besides, the outcome of the research also found that mall promotion has a significant positive relationship with frequency of visits in which this finding 
is supported by Anselmsson (2006). Lastly, the outcome of this study has shown that the relationship between frequency of visits and purchase intention was significant in which the finding is supported by Wakefield \& Baker (1998).

\section{Theoretical and Practical Implications}

In view of the shopping malls are booming in the area of Klang Valley, this study provides a theoretical understanding in identifying the determinants of frequency of visit and purchase intention in the Malaysia retail shopping mall environment.

The results shown that theoretically all the variables namely, convenience, tenant variety, functional attributes, hedonistic value and communication \& promotion can create positive impacts on the shoppers' frequency of visit to the shopping mall. In addition, the study also concludes that frequency of visit has positive impact on the purchase intention among the shoppers in Malaysia. As such, this research has provided useful insights for the mall managers or retailing manager.

The key concern for the management of the shopping mall is to retain the customers' loyalty and at the same time attract more customers to visit. Therefore, the results shown above have suggested that mall management to use the various variables as stated above, as a tool to influence and attract customers' intention to visit and patronize the mall. For example, the mall management should emphasise the elements of convenience, functional attributes, hedonistic value, tenant variety and marketing promotion in drafting the retail strategies to attract the customer traffic flow into the mall.

\section{Conclusion and Future Research}

Several limitations were encountered when conducting this survey. One of the major limitations is that the study may not be generalized to other parts of Malaysia mainly due to the areas of study were only limited to Klang Valley. Besides, it was also found that most of the respondents who responded on this survey were aged 21-29 years old. This may have some biases by the domination of younger shoppers over the older ones. Secondly, the respondents who participate in this study were randomly picked regardless of race, however, some respondents may prefer other languages rather than English in replying the survey questionnaires. External factors such as general election and zeroization of GST 
may also deter the likelihood of intention of purchase and frequency of visit to shopping mall.

There are several suggestions could be used for improvement for future research. Firstly, future research should be conducted throughout the Malaysia especially at the main cities of each states in Malaysia with the purpose to generate more insightful and accurate market information. Besides, as mentioned, language is also a barrier for some respondents to understand. As such, bilanguage such as English and Bahasa Melayu should be drafted into the questionnaire to reduce the language barrier. Besides, although results may provide relevant and deep understanding to the readers as well as retailers or mall management on the attributes that influence the factor of visit to shopping mall, however, it was unknown that the results can be used for other retailing formats. As such, future research could examine this research results whether it can be generalised to other retailing formats.

\section{References}

[1] Ahmed, Z., Ghingold, M \& Dahari, Z. (2007). Malaysian shopping mall behavior: an exploratory study, Asia Pacific Journal of Marketing and Logistics, Vol. 19, No. 4, pp. 331 348.

[2] Ailawadi, KL, Beauchamp, JP, Donthu, N, Gauri, DK \& Shankar, V. (2009). Communication and promotion decisions in retailing: a review and directions for future research, Journal of Retailing, Vol. 85 No. 1, pp. $42-55$.

[3] Ali, M \& Anuar, K. (2013). A structural equation modelling approaches on factors of shopping mall attractiveness that influence consumer decision-making in choosing a shopping mall, Journal of Global Business Economy, Vol. 6, No. 1, pp. $63-76$.

[4] Anselmsson, J. (2006). Sources of customer satisfaction with shopping malls: a comparative study of different customer segments, International Review of Retail, Distribution \& Consumer Research, Vol. 16, No. 1, pp. $115-138$.

[5] Anselmsson, J. (2016). Effects of shopping centre re-investments and improvements on sales and visit growth, Journal of Retailing \& Consumer Services, Vol. 32, No. 1, pp. $139-150$.

[6] Armstrong, JS \& Overton, TS. (1977). Estimating Nonresponse Bias in Mail Surveys, Journal of Marketing Research, Vol. 14, pp. $396-402$.

[7] Aziz, A. (2017). Klang Valley retail occupancy rate at 5-year low, viewed 7 July 2018, <http://www.theedgemarkets.com/article/klang-valley-retail-occupancy-rate-5year-low>.

[8] Bäckström, K. (2011). Shopping as leisure: an exploration of manifoldness and dynamics in consumers shopping experiences, Journal of Retailing \& Consumer Services, Vol. 18, No. 3, pp. $200-209$. 
[9] Baker, J and Wakefield, KL. (2012). How consumer shopping orientation influences perceived crowding, excitement and stress at the mall, Journal of the Academy of Marketing Science, Vol. 40, No. 6, pp. $791-806$.

[10] Baker, JA, Parasuraman, A, Grewal, D \&Voss, GB. (2002). The influence of multiple store environment cues on perceived merchandise value and patronage intentions, Journal of Marketing, Vol. 66, No. 2, pp. $120-141$.

[11] Baron, RM \& Kenny, DA. (1986). The moderator-mediator variable distinction in social psychological research: Conceptual, strategic, and statistical considerations, vol. 51, no. 6, pp. 1173-1182.

[12] Begum, K. (2018). Tough times ahead for mall operators?, viewed 7 July 2018, <https://www.nst.com.my/property/2018/04/356315/tough-times-ahead-mall-operators>.

[13] Bellenger, D, Barnett, A, Greenberg, R and Robertson, R. (1977). Shopping center patronage motives, Journal of Retailing, Vol. 53, No. 2, pp. $29-38$.

[14] Bettman, JR. (1979). An Information Processing Theory of Consumer Choice, Adison-Wesley, Reading.

[15] Biesanz, J.C, Falk, C F \& Savalei, V. (2010). Assessing mediational models: Testing and interval estimation for indirect effects, Multivariate Behavioral Research, Vol. 45, no. 4, pp. 661-701.

[16] Bloch, PH, Ridgway, NM \& Dawson, SA. (1994). The shopping mall as consumer habitant, Journal of Retail, Vol. 70, No. 1, pp. $23-42$.

[17] Borgers, A \& Vosters, C. (2011). Assessing preferences for mega shopping centres: a conjoint measurement approach, Journal of Retailing \& Consumer Services, Vol. 18, No. 4, pp. $322-$ 332.

[18] Calvo-Porral, C \& Levy-Mangin, J-P. (2018). Pull factors of the shopping malls: an empirical study, International Journal of Retail \& Distribution Management, Vol. 46, No. 2, pp. 110 124.

[19] Chebat, JC, Sirgy, MJ \& Grzeskowiak, S. (2010). How can shopping mall management best capture mall image?, Journal of Business Research, Vol. 63 No. 7, pp. 735 - 740.

[20] Chebat, JC, Michon, R, Haj-Salem, N and Oliveira, S. (2014). The effects of mall renovation on shopping values, satisfaction and spending behaviour, Journal of Retailing \& Consumer Services, Vol. 21, No. 4, pp. $610-618$.

[21] Christopher, S. (1961). Research on mail surveys, Journal of the Royal Statistical Society, Vol. A, No. 124, pp. $143-191$.

[22] Clarissa, C \& Hanis, Z. (2018). Sales up 20\% during Tax Holiday, viewed 7 July 2018, $<$ https://www.thestar.com.my/news/nation/2018/06/19/sales-up-20-during-tax-holidaybusinesses-recorded-an-increase-in-shoppers-and-spending/>.

[23] Clulow, V \& Reimers, V. (2009). Retail centres: it's time to make them convenient, International Journal of Retail \& Distribution Management, Vol. 37, No. 7, pp. $541-562$.

[24] Correia-Loureiro, SM \& Roschk, H. (2014). Differential effects of atmospheric cues on emotions and loyalty intentions with respect to age under online/offline environment, Journal of Retailing \& Consumer Services, Vol. 21, No. 2, pp. $211-219$. 


\section{HOLISTICA Vol 10, Issue 3, 2019}

[25] Cote, JA, and Buckley, R. (1987). Estimating Trait, Method, and Error Variance: Generalizing across 70 Construct Validation Studies, Journal of Marketing Research, Vol. 24, No. 3, pp. 315 $-318$.

[26] Damian, DS, Dias-Curto, J \& Castro-Pinto, J. (2011). The impact of anchor stores on the performance of shopping centres: the case of Sonae Sierra, International Journal of Retail \& Distribution Management, Vol. 39, No. 6, pp. $456-475$.

[27] Daniel, WW. (1975). Nonresponse in sociological surveys: A review of some methods for handling the problem, Sociological Methods and Research, Vol. 3, pp. $291-307$.

[28] Davis, L \& Hodges, N. (2012). Consumer shopping value: an investigation of shopping trip value, in store shopping value and retail format, Journal of Retailing \& Consumer Services, Vol. 19, No. 2, pp. $229-239$.

[29] DeLisle, JR. (2005). US shopping center classifications: challenges and opportunities, Research Review, Vol. 12, No. 2, pp. $96-101$.

[30] Dennis, C, Newman, A, Michon, R, Brakus, J \& Wright, L. (2010). The mediating effects of perception and emotion: digital signage in mall atmospherics, Journal of Retailing \& Consumer Services, Vol. 17, No. 3, pp. $205-215$.

[31] Department of Statistics of Malaysia. (2011). Population distribution and basic demographic characteristic report 2010, viewed 7 July 2018, <www.statistics.gov.my>.

[32] El-Adly, MI. (2007). Shopping malls attractiveness: a segmentation approach, International Journal of Retail \& Distribution Management, Vol. 35, No. 11, pp. 936 - 950.

[33] El-Adly, MI \& Eid, R. (2015). Measuring the perceived value of malls in a non-Western context: the case of the UAE, International Journal of Retail \& Distribution Management, Vol. 43, No. 9 , pp. $849-869$.

[34] El-Adly, MI \& Eid, R. (2017). Dimensions of the perceived value of the malls: Muslim's shoppers perspective, International Journal of Retail \& Distribution Management, Vol. 45, No. 1, pp. $40-56$.

[35] El Hedhli, K, Chebat, JC and Sirgy, JM. (2013). Shopping well-being at the mall: constructs, antecedents and consequences, Journal of Business Research, Vol. 66, No. 1, pp. 856-863.

[36] Field, A 2005, Discovering statistics using spss, SAGE, London.

[37] Finn, A \& Louviere, JJ. (1996). Shopping center image, consideration, and choice: anchor store contribution, Journal of Business Research, Vol. 35, No. 3, pp. $241-251$.

[38] Gilboa, S \& Vilnai-Yavetz, I. (2013). Shop until you drop? An exploratory analysis of mall experiences, European Journal of Marketing, Vol. 47, No. 2, pp. $239-259$.

[39] Grewal, D, Levy, M and Kumar, V. (2009). Customer experience management in retailing: an organizing framework, Journal of Retailing, Vol. 85, No. 1, pp. $1-14$.

[40] Hair, JF, Black, WC, Babin, BJ, Anderson, RE \& Tatham, RL. (2014). Multivariate data analysis, 5th edition, Pearson, New Jersey.

[41] Howard, E. (1993). Assessing the impact of shopping-centre development: the Meadowhall case, Journal of Property Research, Vol. 10, No. 2, pp. $97-119$.

[42] Hendricks, WA. (1949). Adjustment for bias by non-response in mail surveys, Agricultural Economics Research, Vol. 1, $52 \mathrm{ff}$.

[43] Kanuk, L \& Berenson, C. (1975). Mail surveys and response rates: A literature review, Journal of Marketing Research, Vol. 12, pp. $440-453$. 
[44] Kesari, B \& Atulkar, S. (2016). Satisfaction of mall shoppers: a study on perceived utilitarian and hedonic shopping values, Journal of Retailing \& Consumer Services, Vol. 31, No. 1, pp. 22 $-31$.

[45] Khare, A. (2011). Mall shopping behavior of Indian small town consumers, Journal of Retail and Consumer Service, Vol. 18, No. 1, pp. $110-118$.

[46] Kim, H \& Kim, Y. (2008). Shopping enjoyment and store shopping modes: the moderating influence of chronic time pressure, Journal of Retailing \& Consumer Services, Vol. 15, No. 5, pp. $410-419$.

[47] Kotler, P. (1973). Atmospherics as a marketing tool, Journal of Retailing, Vol. 49, No. 4, pp. 48 $-64$.

[48] Leslie, K. (1965). Survey Sampling, New York: John Wiley and Sons, Inc.

[49] Levy, M, Weitz, B \& Pandit, A 2012 Retail Management, 8th ed, McGraw Hill Education, New Delhi.

[50] Linsky, AS. (1975). Stimulating responses to mailed questionnaires: A review, Public Opinion Quarterly, Vol. 30, pp. $82-101$.

[51] Mahalingam, E. (2016). Onslaught of Shopping Centres, viewed 7 July 2018, $<$ https://www.thestar.com.my/business/business-news/2016/02/13/onslaught-ofshopping-centres/>.

[52] Mahalingam, E. (2017). The Thriving Retail Sector, viewed 7 July 2018, <https://www.thestar.com.my/business/business-news/2017/12/16/the-thriving-retailsector/>.

[53] Mahalingam, E. (2018). SST Seen To Affect Retail Sales, viewed 1 August 2018, $<$ https://www.thestar.com.my/business/business-news/2018/07/18/sst-seen-to-affectretail-sales/>.

[54] Malhotra, NK, Kim, SS \& Patil, A. (2006). Common Method Variance in IS Research: A Comparison of Alternative Approaches and a Reanalysis of Past Research, Management Science, Vol. 52, No. 12, pp. $1865-1883$.

[55] Malhotra, NK. (2010). Marketing research, 6th edition, Pearson, New Jersey.

[56] Michon, R, Yu, H, Smith, D \& Chebat, JC. (2008). The influence of mall environment on female shoppers' value and behaviour, Journal of Fashion Marketing Management, Vol. 12, No. 4, pp. $456-468$.

[57] Munuera, JL \& Cuestas, PJ. (2006). Factores de atracción de los Centros Comerciales en España: Tendencias de la distribución commercial en el ámbito internacional, ICE, Vol.828, No.1, pp.99- 116.

[58] Nelson, RL. (1958). The selection of retail location, Dodge Corporation, New York.

[59] Nsairi, ZB. (2012). Managing browsing experience in retail stores through perceived value: implications for retailers, International Journal of Retail \& Distribution Management, Vol. 40, No. 9, pp. $676-698$.

[60] Oliver, RL, Rust, RT \& Varki, S. (1997). Customer delight: foundations, findings, and managerial insight, Journal of Retailing, Vol. 73, No. 3, pp. $311-336$.

[61] Pan, Y \& Zinkhan, GM. (2006). Determinants of retail patronage: a meta-analytical perspective, Journal of Retailing, Vol. 82, No. 3, pp. $229-243$. 
[62] Peiser, RB \& Frej, AB. (2003). Professional Real Estate Development: The ULI Guide to the Business, 2nd ed., Urban Land Institute, Washington, DC.

[63] Podsakoff, PM, MacKenzie, SB, Lee, JY \& Podsakoff, NP. (2003). Common method biases in behavioral research; A critical review of the literature and recommended remedies, Journal of Applied Psychology, vol. 88, no. 5, pp. 879-903.

[64] Podsakoff, PM \& Organ, DW. (1986). Self-Reports in Organizational Research: Problems and Prospects, Journal of Management, Vol. 12, No. 4, pp. $531-544$.

[65] Raajpoot, NA, Sharma, A \& Chebat, JC. (2008). The role of gender and work status in shopping center patronage, Journal of Business Research, Vol. 61, No. 5, pp. $825-833$.

[66] Saunders, M, Lewis, P \& Thornhill, A. (2012). Research Method for Business Students, Pearson Education.

[67] Sinha, PK \& Banerjee. (2004). Store choice behavior in an evolving market, Journal of Retail and Distribution Management, Vol. 32, No. 10, pp $482-494$.

[68] Sinha, PK \& Uniyal, DP. (2005). Using observational research for behavioural segmentation of shoppers, Journal of Retailing \& Consumer Services, Vol. 12 No. 1, pp. $35-48$.

[69] The Star Online. (2018). GST Zero Rated From June 1, viewed 7 July 2018, <https://www.thestar.com.my/news/nation/2018/05/16/gst-zero-rated-from-june-1/>.

[70] Stephan, FF \& McCarthy, PJ, Sampling Opinions, New York: John Wiley and Sons, Inc.

[71] Tabachnik, BG \& Fidell, LS. (2007). Using Multivariate Statistics, 5th edn, Pearson Education, Boston.

[72] Tarun, K, Ubeja, S \& Chatterjee, AS, 'Factors Influencing Selection of Shopping Malls: An Exploratory Study of Consumer Perception', Journal of Business Perspective, Vol. 21, No.3, pp. $274-283$.

[73] Thean, LC. (2018). Retail sector enters consolidation phase, viewed 7 July 2018, <https://www.thestar.com.my/business/business-news/2018/02/05/retail-sector-entersconsolidation-phase/>.

[74] Tsai, SP. (2010). Shopping mall management and entertainment experience: across-regional investigation, Services Industry Journal, Vol. 30, No. 3, pp. 321 - 337.

[75] Tourangeau, R, Rips, L, \& Rasinski, K. (2000). The psychology of survey response, Cambridge, England: Cambridge University Press.

[76] Wakefield, KL \& Baker, J. (1998). Excitement at the mall: determinants and effects on shopping response, Journal of Retailing, Vol. 74, No. 4, pp. $515-539$.

[77] Yan, RN \& Eckman, M. (2009). Are lifestyle centers unique? Consumers' perceptions across locations, International Journal of Retail \& Distribution Management, Vol. 37, No. 1, pp. 24 42.

[78] Zikmund, WG, Babin, BJ, Carr, JC \& Griffin, M. (2010). Business Research Method, 8th edn, Cengage Learning. 